NASA/TM-2000-209891, Vol. 48

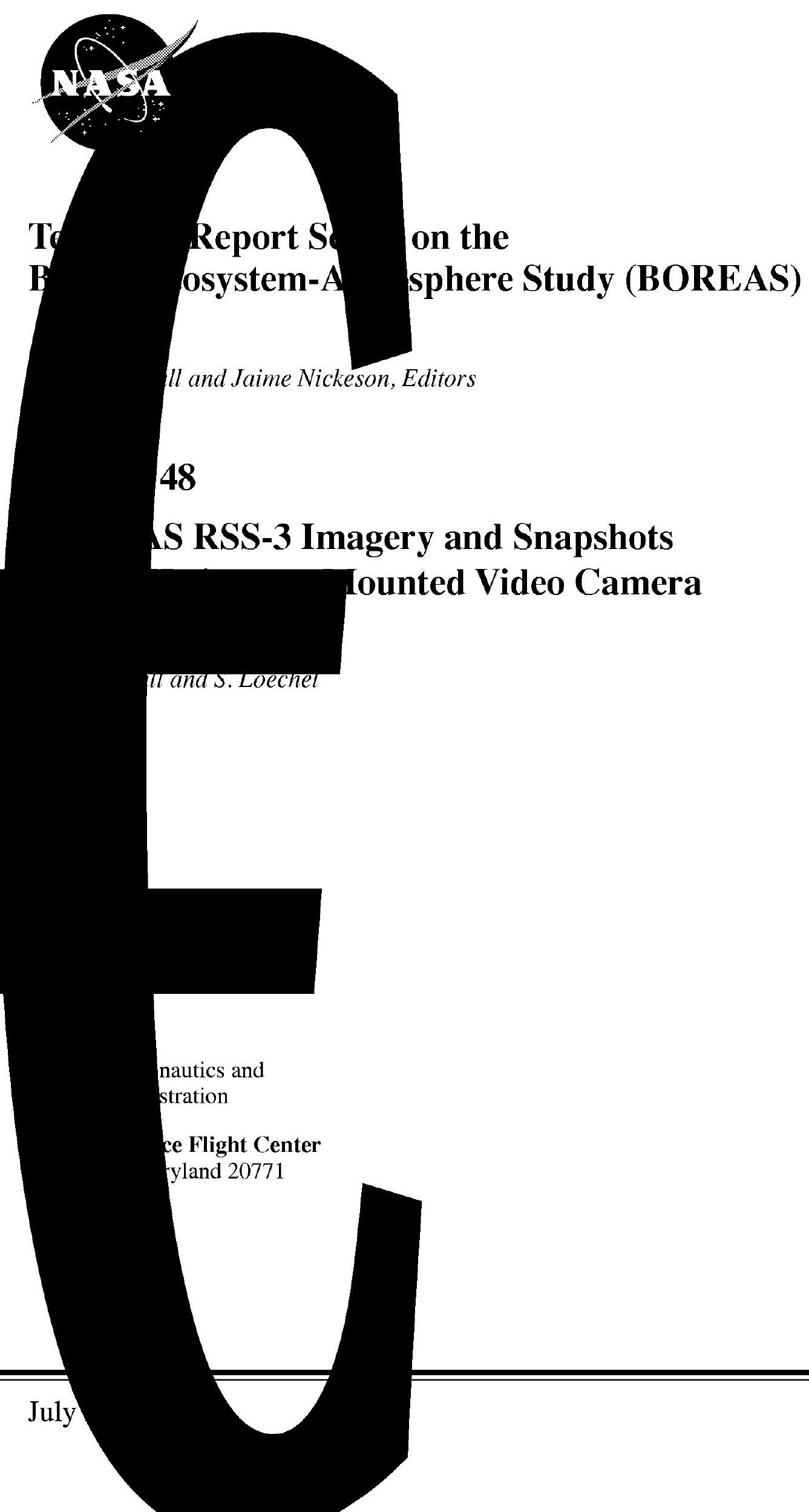


The NASA STI Program Office ... in Profile

Since its founding, NASA has been dedicated to the advancement of aeronautics and space science. The NASA Scientific and Technical Information (STI) Program Office plays a key part in helping NASA maintain this important role.

The NASA STI Program Office is operated by Langley Research Center, the lead center for NASA's scientific and technical information. The NASA STI Program Office provides access to the NASA STI Database, the largest collection of aeronautical and space science STI in the world. The Program Office is also NASA's institutional mechanism for disseminating the results of its research and development activities. These results are published by NASA in the NASA STI Report Series, which includes the following report types:

- TECHNICAL PUBLICATION. Reports of completed research or a major significant phase of research that present the results of NASA programs and include extensive data or theoretical analysis. Includes compilations of significant scientific and technical data and information deemed to be of continuing reference value. NASA's counterpart of peer-reviewed formal professional papers but has less stringent limitations on manuscript length and extent of graphic presentations.

- TECHNICAL MEMORANDUM. Scientific and technical findings that are preliminary or of specialized interest, e.g., quick release reports, working papers, and bibliographies that contain minimal annotation. Does not contain extensive analysis.

- CONTRACTOR REPORT. Scientific and technical findings by NASA-sponsored contractors and grantees.
- CONFERENCE PUBLICATION. Collected papers from scientific and technical conferences, symposia, seminars, or other meetings sponsored or cosponsored by NASA.

- SPECIAL PUBLICATION. Scientific, technical, or historical information from NASA programs, projects, and mission, often concerned with subjects having substantial public interest.

- TECHNICAL TRANSLATION. English-language translations of foreign scientific and technical material pertinent to NASA's mission.

Specialized services that complement the STI Program Office's diverse offerings include creating custom thesauri, building customized databases, organizing and publishing research results ... even providing videos.

For more information about the NASA STI Program Office, see the following:

- Access the NASA STI Program Home Page at http://www.sti.nasa.gov/STI-homepage.html

- E-mail your question via the Internet to help@sti.nasa.gov

- Fax your question to the NASA Access Help Desk at (301) 621-0134

- Telephone the NASA Access Help Desk at (301) 621-0390

- Write to:

NASA Access Help Desk

NASA Center for AeroSpace Information 7121 Standard Drive Hanover, MD 21076-1320 
NASA/TM-2000-209891, Vol. 48

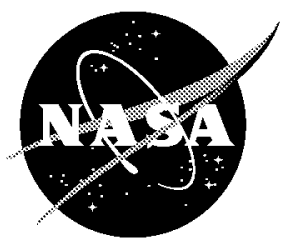

Technical Report Series on the Boreal Ecosystem-Atmosphere Study (BOREAS)

Forrest G. Hall and Jaime Nickeson, Editors

\section{Volume 48}

\section{BOREAS RSS-3 Imagery and Snapshots from a Helicopter-Mounted Video Camera}

Charles L. Walthall, U.S.D.A. Agricultural Research Service, Beltsville, Maryland Sara Loechel, University of Maryland

National Aeronautics and

Space Administration

Goddard Space Flight Center

Greenbelt, Maryland 20771 


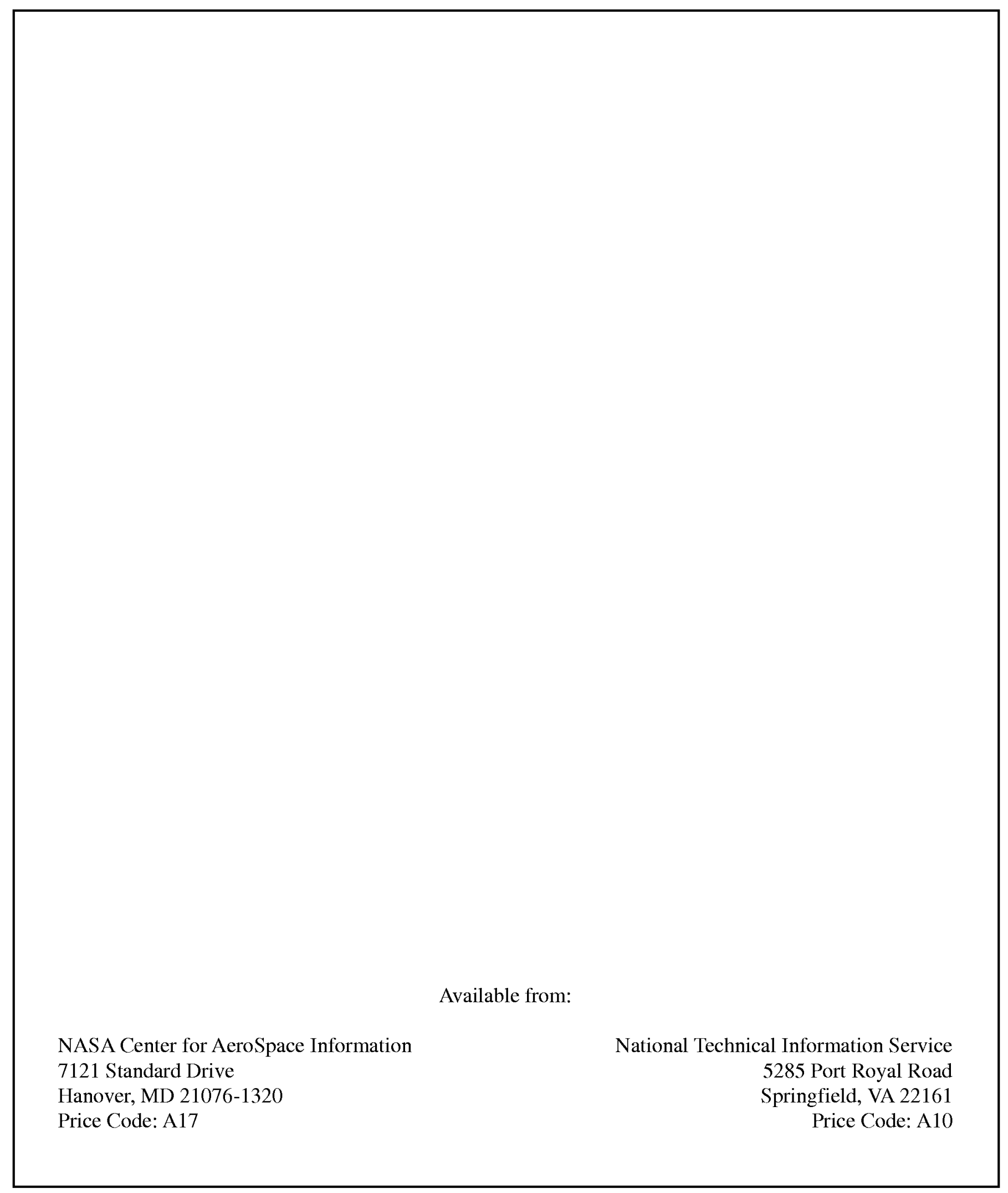




\title{
BOREAS RSS-3 Imagery and Snapshots from a Helicopter-Mounted Video Camera
}

\author{
Charles L. Walthall, Sara Loechel
}

\section{Summary}

The BOREAS RSS-3 team collected helicopter-based video coverage of forested sites acquired during BOREAS as well as single-frame "snapshots" processed to still images. Helicopter data used in this analysis were collected during all three 1994 IFCs (24-May to 16-Jun, 19-Jul to 10-Aug, and 30-Aug to 19-Sep), at numerous tower and auxiliary sites in both the NSA and the SSA. The VHS-camera observations correspond to other coincident helicopter measurements. The field of view of the camera is unknown. The video tapes are in both VHS and Beta format. The still images are stored in JPEG format.

Note: An extensive helicopter log (in Acrobat format) is available for the 1994 IFC's. Environmental, technical, instrumental, and operational conditions are noted for each observation where applicable. It is strongly recommended that any researcher doing extended work with this data set review this helicopter log.

\section{Table of Contents}

1) Data Set Overview

2) Investigator(s)

3) Theory of Measurements

4) Equipment

5) Data Acquisition Methods

6) Observations

7) Data Description

8) Data Organization

9) Data Manipulations

10) Errors

11) Notes

12) Application of the Data Set

13) Future Modifications and Plans

14) Software

15) Data Access

16) Output Products and Availability

17) References

18) Glossary of Terms

19) List of Acronyms

20) Document Information

\section{Data Set Overview}

\subsection{Data Set Identification}

BOREAS RSS-03 Imagery and Snapshots from a Helicopter-Mounted Video Camera

\subsection{Data Set Introduction}

The Remote Sensing Science (RSS)-03 helicopter-based video data set was compiled during the BOReal Ecosystem-Atmosphere Study (BOREAS) 1994 Intensive Field Campaigns (IFCs) with a color VHS video camera mounted on a helicopter platform. Video imagery was taken from the helicopter platform at BOREAS sites simultaneous with radiometric ground measurements and 
sunphotometer measurements from the same platform. The instrumentation used was designed and developed at the National Aeronautics and Space Administration (NASA) Goddard Space Flight Center (GSFC). The data were collected during the green-up, peak, and senescent stages of the growing season at numerous tower and auxiliary sites in both the Northern Study Area (NSA) and the Southern Study Area (SSA). The images were taken during the following periods:

- $\quad$ 31-May-1994 to 10-Jun-1994 (IFC-1)

- 21-Jul-1994 to 08-Aug-1994 (IFC-2)

- $\quad$ 06-Sep-1994 to 16-Sep-1994 (IFC-3)

Multiple observations were captured from the video at sites where the cover changed significantly during the scan time; this was determined subjectively by the operator.

\subsection{Objective/Purpose}

The study objective was to acquire multispectral, bidirectional reflectance, and surface temperature data of the study sites for assessments of spectral, spatial, and temporal variability, and the impacts of these variabilities on vegetation indices. A helicopter with a pointable, stabilized mount was used to carry a spectrometer (visible and near-infrared), spectroradiometer, infrared thermometer, video camera, and a sun tracking photometer.

\subsection{Summary of Parameters}

Helicopter-based VHS video photographs of tower and auxiliary sites during all three IFCs in 1994. Video observations were captured while onboard devices were in operation over sites.

\subsection{Discussion}

The video imagery was taken to capture visual conditions at the site during data collection that could then later be referred to as necessary when processing the data to aid in the quality assessment of the data.

\subsection{Related Data Sets}

BOREAS RSS-01 PARABOLA Surface Reflectance and Transmittance Data

BOREAS RSS-02 Level-1b ASAS Imagery: At-sensor Radiance in BSQ Format

BOREAS RSS-03 Reflectance Measured from a Helicopter-Mounted SE-590

BOREAS RSS-03 Reflectance Measured from a Helicopter-Mounted Barnes MMR

BOREAS RSS-03 Atmospheric Conditions from a Helicopter-Mounted Sunphotometer

BOREAS RSS-19 Background Spectral Reflectance Data

BOREAS RSS-20 POLDER Measurements of Surface BRDF

\section{Investigator(s)}

\subsection{Investigator(s) Name and Title}

Dr. Charles L. Walthall, Physical Scientist

\subsection{Title of Investigation}

Biophysical Significance of Spectral Vegetation Indices in the Boreal Forest 


\subsection{Contact Information}

\section{Contact 1:}

Dr. Charles L. Walthall

Physical Scientist

USDA Agricultural Research Service

Remote Sensing and Modeling Laboratory

Rm. 008, Bldg. 007, BARC-West

10300 Baltimore Avenue

Beltsville, MD 20705 USA

(301) 504-6074

(301) 504-5031 (fax)

cwalthal@asrr.arsusda.gov

\section{Contact 2:}

Sara Loechel

Faculty Research Assistant

Department of Geography

University of Maryland

Remote Sensing and Modeling Laboratory

Rm. 008, Bldg. 007, BARC-West

10300 Baltimore Avenue

Beltsville, MD 20705 USA

(301) 504-6823

(301) 504-5031 (fax)

sloechel@asrr.arsusda.gov

\section{Contact 3:}

Jaime Nickeson

Raytheon ITSS

NASA GSFC

Code 923

Greenbelt, MD 20771

(301) 286-3373

(301) 286-0239 (fax)

Jaime.Nickeson@gsfc.nasa.gov

\section{Theory of Measurements}

The video imagery was taken to capture visual conditions at the site during data collection that could then later be referred to as necessary when processing the data to aid in the quality assessment. Two video cameras are used in the system. One video camera is bore-sighted with the main instruments on the pointable platform, and the other is next to the $70 \mathrm{~mm}$ photographic camera set to view nadir only. Video data are fed through a time and date video generator to superimpose month, day, year, and system clock time on the video tape frames. 


\section{Equipment}

\subsection{Sensor/Instrument Description}

Color Video System. The color video system consists of Charge-Coupled Device (CCD)-based color video cameras connected to a stereo-audio VCR. During IFC-1 and IFC-2, the VCR was a Beta format unit that had been used with the helicopter system since the mid-1980s. Beta format was originally chosen over VHS to take advantage of its higher video image resolution. Prior to IFC-3, an industrial-quality Super-VHS unit was installed and used for the rest of the experiment.

The image is then displayed on a 14-inch color screen in the center instrument rack. Images from the nadir-only viewing camera are fed directly to a small color screen located on the pilot's instrument panel and then to a selector switch. The selector switch allows the back-seat instrument operators to view either the images from the bore-sighted video camera or the pilot's video camera. The bore-sighted camera provides feedback to the instrument operator when pointing the instrument package, and the nadir camera image is used by the pilot while positioning the helicopter during hovers. During IFC-1, a video camera with an operator-controlled electronic zoom and focus system with a was used. During IFC-2 and IFC-3, this lens was replaced with the same type of lens used with the nadir-looking camera. These lenses had a manual focus and a 20 to $80 \mathrm{~mm}$ zoom range, which was set at 30 to $35 \mathrm{~mm}$.

The stereo audio tracks of the VCR are used for an additional data record. One track is used to record an audible tone that is generated each time the instruments are triggered. The other audio track records the cabin intercom conversations among the aircrew.

\subsubsection{Collection Environment}

In general, the helicopter was flown during relatively clear days when possible. Data collection was attempted during conditions of highest possible solar elevation. All observations were attempted from a nadir observation point and usually at $300 \mathrm{~m}$ above ground level (AGL). Exceptions are noted in the helicopter $\log$.

\subsubsection{Source/Platform}

A Bell UH-1H "Iroquois" helicopter, operated by the NASA's Wallops Flight Facility (WFF) was used as the airborne platform during BOREAS. This particular aircraft, call number N415, was built in 1965 and was acquired by WFF in 1993. Upon acquisition, the aircraft was slightly modified for use as a scientific platform.

Helicopter N415 operates with standard or low-mount, rear-leaning skids. The engine is a Lycoming T53/L13, which provides 1,400 shaft HP with 1,290 transmission HP. The fuel capacity provides 2.0 hours flying time with a 20 minute fuel reserve under normal modes of operation. The addition of an auxiliary fuel tank in the port-side door crewman's position provided an additional 15 minutes of flight time during BOREAS given optimum flight conditions. The weight of the entire helicopter system with full instrumentation, full fuel, and crew members was 9,500 lbs.

\subsubsection{Source/Platform Mission Objectives}

The video imagery was collected to capture site conditions at a fine spatial resolution during data collection that could then later be referred to as necessary when processing the data and to aid in the quality assessment of the data.

\subsubsection{Key Variables}

Video imagery.

\subsubsection{Principles of Operation}

The system is configured for multiple sensor data collection. The Modular Multiband Radiometer (MMR), Spectron Engineering spectroradiometer (SE-590), infrared thermometer, autotracking sunphotometer, and video sensor were the primary payload during BOREAS. The video camera was run continuously during data collection. 


\subsubsection{Sensor/Instrument Measurement Geometry}

Unknown.

\subsubsection{Manufacturer of Sensor/Instrument}

Unknown.

\subsection{Calibration}

Images are not calibrated. However, the images provide an overhead view of the tower and auxiliary sites with fine spatial resolution.

\subsubsection{Specifications}

\subsubsection{Tolerance}

Not applicable.

\subsubsection{Frequency of Calibration}

Not applicable.

\subsubsection{Other Calibration Information}

Not applicable.

\section{Data Acquisition Methods}

The NASA GSFC/WFF helicopter-based optical remote sensing system was deployed to acquire canopy multispectral data while hovering approximately 300 meters AGL (Walthall et al., 1996). A VHS color video camera was in operation during all data collection flights. The field of view (FOV) of the lens is unknown. Images are not calibrated. However, the images provide an overhead view of the tower and auxiliary sites with fine spatial resolution. A visual record of conditions at the time of the spectral data collection can assist in analysis.

The video snapshots were generated on a Power Macintosh PC 8500/220 using a VHS video player and Avid VideoShop 3.0.2. The images were then converted from PICT format to JPEG for universal accessibility.

\section{Observations}

\subsection{Data Notes}

An extensive helicopter log is available. Environmental, technical, instrumental, and operator conditions are noted for each observation where applicable.

\subsection{Field Notes}

See helicopter log. 


\section{Data Description}

\subsection{Spatial Characteristics}

\subsubsection{Spatial Coverage}

The helicopter visited all of the NSA and SSA tower and category-1 auxiliary sites. Each site listed below was observed by this instrument at least once during the 1994 campaign at BOREAS. The coordinates in the table are based on the North American Datum of 1983 (NAD83).

\begin{tabular}{|c|c|c|c|c|c|c|c|c|}
\hline Site Id & $\begin{array}{l}\text { Operat' } 1 \\
\text { Grid ID }\end{array}$ & Longitude & & Latitude & & $\begin{array}{l}\text { UTM } \\
\text { Easting }\end{array}$ & $\begin{array}{l}\text { UTM } \\
\text { Northing }\end{array}$ & $\begin{array}{l}\text { UTM } \\
\text { Zone }\end{array}$ \\
\hline \multicolumn{9}{|c|}{$\begin{array}{l}\text { Flux Tower Sites } \\
\text { SSA: }\end{array}$} \\
\hline SSA-FEN & FOL9T & $104.61798^{\circ}$ & $W$ & $53.80206^{\circ}$ & $\mathrm{N}$ & 525159.8 & 5961566.6 & 13 \\
\hline SSA-OBS & $\mathrm{G} 8 \mathrm{I} 4 \mathrm{~T}$ & $105.11779^{\circ}$ & $W$ & $53.98717^{\circ}$ & $\mathrm{N}$ & 492276.5 & 5982100.5 & 13 \\
\hline SSA-OJP & $\mathrm{G} 2 \mathrm{~L} 3 \mathrm{~T}$ & $104.69203^{\circ}$ & $W$ & $53.91634^{\circ}$ & $\mathrm{N}$ & 520227.7 & 5974257.5 & 13 \\
\hline$S S A-Y J P$ & $\mathrm{~F} 8 \mathrm{~L} 6 \mathrm{~T}$ & $104.64529^{\circ}$ & W & $53.87581^{\circ}$ & $\mathrm{N}$ & 523320.2 & 5969762.5 & 13 \\
\hline SSA-9OA & $\mathrm{C} 3 \mathrm{~B} 7 \mathrm{~T}$ & $106.19779^{\circ}$ & $W$ & $53.62889^{\circ}$ & $\mathrm{N}$ & 420790.5 & 5942899.9 & 13 \\
\hline SSA-9YA & $\mathrm{DOH} 4 \mathrm{~T}$ & $105.32314^{\circ}$ & $W$ & $53.65601^{\circ}$ & $\mathrm{N}$ & 478644.1 & 5945298.9 & 13 \\
\hline \multicolumn{9}{|c|}{ 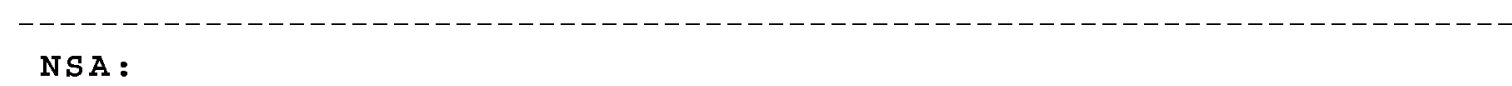 } \\
\hline NSA-OBS & T3R8T & $98.48139^{\circ}$ & $W$ & $55.88007^{\circ}$ & $\mathrm{N}$ & 532444.5 & 6192853.4 & 14 \\
\hline NSA-OJP & $\mathrm{T} 708 \mathrm{~T}$ & $98.62396^{\circ}$ & $W$ & $55.92842^{\circ}$ & $\mathrm{N}$ & 523496.2 & 6198176.3 & 14 \\
\hline NSA-YJP & T8S9T & $98.28706^{\circ}$ & $W$ & $55.89575^{\circ}$ & $\mathrm{N}$ & 544583.9 & 6194706.9 & 14 \\
\hline NSA-BVP & $\mathrm{T} 4 \mathrm{U} 6 \mathrm{~T}$ & $98.02747^{\circ}$ & $W$ & $55.84225^{\circ}$ & $\mathrm{N}$ & 560900.6 & 6188950.7 & 14 \\
\hline NSA-FEN & $\mathrm{T} 7 \mathrm{~S} 1 \mathrm{~T}$ & $98.42072^{\circ}$ & $W$ & $55.91481^{\circ}$ & $\mathrm{N}$ & 536207.9 & 6196749.6 & 14 \\
\hline------ & 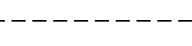 & s & & - & - & -------1 & --------1 & 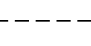 \\
\hline \multicolumn{9}{|c|}{$\begin{array}{l}\text { Auxiliary Sites } \\
\text { SSA: }\end{array}$} \\
\hline$S S A-9 B S$ & D0H6S & $105.29534^{\circ}$ & $W$ & $53.64877^{\circ}$ & $\mathrm{N}$ & 480508.7 & 5944263.4 & 13 \\
\hline$S S A-9 B S$ & G2I4S & $105.13964^{\circ}$ & $W$ & $53.93021^{\circ}$ & $\mathrm{N}$ & 490831.4 & 5975766.3 & 13 \\
\hline$S S A-9 B S$ & G2L $7 \mathrm{~S}$ & $104.63785^{\circ}$ & $W$ & $53.90349^{\circ}$ & $\mathrm{N}$ & 523793.6 & 5972844.3 & 13 \\
\hline$S S A-9 B S$ & $\mathrm{G} 6 \mathrm{~K} 8 \mathrm{~S}$ & $104.75900^{\circ}$ & $W$ & $53.94446^{\circ}$ & $\mathrm{N}$ & 515847.9 & 5977146.9 & 13 \\
\hline$S S A-9 B S$ & G9I4S & $105.11805^{\circ}$ & $W$ & $53.99877^{\circ}$ & $\mathrm{N}$ & 492291.2 & 5983169.1 & 13 \\
\hline$S S A-9 J P$ & F5I 6P & $105.11175^{\circ}$ & $W$ & $53.86608^{\circ}$ & $\mathrm{N}$ & 492651.3 & 5968627.1 & 13 \\
\hline$S S A-9 J P$ & F7JOP & $105.05115^{\circ}$ & $W$ & $53.88336^{\circ}$ & $\mathrm{N}$ & 496667.0 & 5970323.3 & 13 \\
\hline$S S A-9 J P$ & $\mathrm{E} 7 \mathrm{~J} 1 \mathrm{P}$ & $105.03226^{\circ}$ & $W$ & $53.88211^{\circ}$ & $\mathrm{N}$ & 497879.4 & 5970405.6 & 13 \\
\hline$S S A-9 J P$ & G1K9P & $104.74812^{\circ}$ & $W$ & $53.90880^{\circ}$ & $\mathrm{N}$ & 516546.7 & 5973404.5 & 13 \\
\hline$S S A-9 J P$ & $\mathrm{G} 4 \mathrm{~K} 8 \mathrm{P}$ & $104.76401^{\circ}$ & $W$ & $53.91883^{\circ}$ & $\mathrm{N}$ & 515499.1 & 5974516.6 & 13 \\
\hline$S S A-9 J P$ & G7K8P & $104.77148^{\circ}$ & $W$ & $53.95882^{\circ}$ & $\mathrm{N}$ & 514994.2 & 5978963.8 & 13 \\
\hline$S S A-9 J P$ & G8L6P & $104.63755^{\circ}$ & $W$ & $53.96558^{\circ}$ & $\mathrm{N}$ & 523778.0 & 5979752.7 & 13 \\
\hline$S S A-9 J P$ & G9LOP & $104.73779^{\circ}$ & $W$ & $53.97576^{\circ}$ & $\mathrm{N}$ & 517197.7 & 5980856.0 & 13 \\
\hline$S S A-9 J P$ & I2I 8P & $105.05107^{\circ}$ & $W$ & $54.11181^{\circ}$ & $\mathrm{N}$ & 496661.4 & 5995963.1 & 13 \\
\hline SSA-ASP & B9B7A & $106.18693^{\circ}$ & $W$ & $53.59098^{\circ}$ & $\mathrm{N}$ & 421469.8 & 5938447.2 & 13 \\
\hline SSA-ASP & $\mathrm{D} 6 \mathrm{H} 4 \mathrm{~A}$ & $105.31546^{\circ}$ & $W$ & $53.70828^{\circ}$ & $\mathrm{N}$ & 479177.5 & 5951112.1 & 13 \\
\hline SSA-ASP & $\mathrm{D} 6 \mathrm{~L} 9 \mathrm{~A}$ & $104.63880^{\circ}$ & W & $53.66879^{\circ}$ & $\mathrm{N}$ & 523864.0 & 5946733.2 & 13 \\
\hline SSA-ASP & D 9G4A & $105.46929^{\circ}$ & $W$ & $53.74019^{\circ}$ & $\mathrm{N}$ & 469047.1 & 5954718.4 & 13 \\
\hline SSA-MIX & D9I1M & $105.20643^{\circ}$ & $W$ & $53.72540^{\circ}$ & $\mathrm{N}$ & 486379.7 & 5952989.7 & 13 \\
\hline SSA-MIX & E1NOM & $104.53300^{\circ}$ & $W$ & $53.80594^{\circ}$ & $\mathrm{N}$ & 530753.7 & 5962031.8 & 13 \\
\hline SSA-MIX & G4 I 3M & $105.14246^{\circ}$ & $W$ & $53.93750^{\circ}$ & $\mathrm{N}$ & 490677.3 & 5976354.9 & 13 \\
\hline SSA-CLR & FRSHCL & $104.69194^{\circ}$ & $W$ & $53.91639^{\circ}$ & $\mathrm{N}$ & 520205.2 & 5974269.4 & 13 \\
\hline
\end{tabular}




\begin{tabular}{|c|c|c|c|c|c|c|c|c|}
\hline Site Id & $\begin{array}{l}\text { Operat' } 1 \\
\text { Grid ID }\end{array}$ & Longitude & & Latitude & & $\begin{array}{l}\text { UTM } \\
\text { Easting }\end{array}$ & $\begin{array}{c}\text { UTM } \\
\text { Northing }\end{array}$ & $\begin{array}{l}\text { UTM } \\
\text { Zone }\end{array}$ \\
\hline \multicolumn{9}{|c|}{$\begin{array}{l}\text { Auxiliary sites } \\
\text { NSA: }\end{array}$} \\
\hline$N S A-9 B S$ & S $8 W 0 S$ & $97.84024^{\circ}$ & $W$ & $55.76824^{\circ}$ & $\mathrm{N}$ & 572761.9 & 6180894.9 & 14 \\
\hline NSA-9BS & TOP7S & $98.82345^{\circ}$ & $W$ & $55.88371^{\circ}$ & $\mathrm{N}$ & 511043.9 & 6193151.1 & 14 \\
\hline NSA-9BS & T0P8S & $98.80225^{\circ}$ & $W$ & $55.88351^{\circ}$ & $\mathrm{N}$ & 512370.1 & 6193132.0 & 14 \\
\hline$N S A-9 B S$ & T0W1S & $97.80937^{\circ}$ & $W$ & $55.78239^{\circ}$ & $\mathrm{N}$ & 574671.7 & 6182502.0 & 14 \\
\hline NSA-9BS & T3U9S & $97.98339^{\circ}$ & $W$ & $55.83083^{\circ}$ & $\mathrm{N}$ & 563679.1 & 6187719.2 & 14 \\
\hline NSA-9BS & $\mathrm{T} 4 \mathrm{U} 8 \mathrm{~S}$ & $97.99325^{\circ}$ & $W$ & $55.83913^{\circ}$ & $\mathrm{N}$ & 563048.2 & 6188633.4 & 14 \\
\hline$N S A-9 B S$ & T4U9S & $97.98364^{\circ}$ & W & $55.83455^{\circ}$ & $\mathrm{N}$ & 563657.5 & 6188132.8 & 14 \\
\hline NSA-9BS & T5Q7S & $98.64022^{\circ}$ & $W$ & $55.91610^{\circ}$ & $\mathrm{N}$ & 522487.2 & 6196800.5 & 14 \\
\hline NSA-9BS & T6R5S & $98.51865^{\circ}$ & $W$ & $55.90802^{\circ}$ & $\mathrm{N}$ & 530092.0 & 6195947.0 & 14 \\
\hline$N S A-9 B S$ & $\mathrm{~T} 6 \mathrm{~T} 6 \mathrm{~S}$ & $98.18658^{\circ}$ & $W$ & $55.87968^{\circ}$ & $\mathrm{N}$ & 550887.9 & 6192987.9 & 14 \\
\hline NSA-9BS & T7R9s & $98.44877^{\circ}$ & $W$ & $55.91506^{\circ}$ & $\mathrm{N}$ & 534454.5 & 6196763.6 & 14 \\
\hline NSA-9BS & T7T3S & $98.22621^{\circ}$ & $W$ & $55.89358^{\circ}$ & $\mathrm{N}$ & 548391.8 & 6194505.6 & 14 \\
\hline$N S A-9 B S$ & T8S4S & $98.37111^{\circ}$ & $W$ & $55.91689^{\circ}$ & $\mathrm{N}$ & 539306.4 & 6197008.6 & 14 \\
\hline$N S A-9 B S$ & U5W5S & $97.70986^{\circ}$ & $W$ & $55.90610^{\circ}$ & $\mathrm{N}$ & 580655.5 & 6196380.8 & 14 \\
\hline NSA-9BS & $\mathrm{U} 6 \mathrm{~W} 5 \mathrm{~S}$ & $97.70281^{\circ}$ & $W$ & $55.91021^{\circ}$ & $\mathrm{N}$ & 581087.8 & 6196846.5 & 14 \\
\hline NSA-9JP & $9909 \mathrm{P}$ & $99.03952^{\circ}$ & $W$ & $55.88173^{\circ}$ & $\mathrm{N}$ & 497527.8 & 6192917.5 & 14 \\
\hline$N S A-9 J P$ & Q3V3P & $98.02473^{\circ}$ & $W$ & $55.55712^{\circ}$ & $\mathrm{N}$ & 561517.9 & 6157222.2 & 14 \\
\hline NSA-9JP & T7S9P & $98.30037^{\circ}$ & $W$ & $55.89486^{\circ}$ & $\mathrm{N}$ & 543752.4 & 6194599.1 & 14 \\
\hline$N S A-9 J P$ & $\mathrm{~T} 8 \mathrm{QPP}$ & $98.61050^{\circ}$ & $W$ & $55.93219^{\circ}$ & $\mathrm{N}$ & 524334.5 & 6198601.4 & 14 \\
\hline$N S A-9 J P$ & T8S9P & $98.28385^{\circ}$ & $W$ & $55.90456^{\circ}$ & $\mathrm{N}$ & 544774.3 & 6195688.9 & 14 \\
\hline$N S A-9 J P$ & T8T1P & $98.26269^{\circ}$ & $W$ & $55.90539^{\circ}$ & $\mathrm{N}$ & 546096.3 & 6195795.3 & 14 \\
\hline NSA-9JP & T9Q8P & $98.59568^{\circ}$ & $W$ & $55.93737^{\circ}$ & $\mathrm{N}$ & 525257.1 & 6199183.2 & 14 \\
\hline NSA-9OA & $\mathrm{T} 2 \mathrm{Q} 6 \mathrm{~A}$ & $98.67479^{\circ}$ & $W$ & $55.88691^{\circ}$ & $\mathrm{N}$ & 520342.0 & 6193540.7 & 14 \\
\hline NSA-ASP & $\mathrm{P} 7 \mathrm{~V} 1 \mathrm{~A}$ & $98.07478^{\circ}$ & $W$ & $55.50253^{\circ}$ & $\mathrm{N}$ & 558442.1 & 6151103.7 & 14 \\
\hline NSA-ASP & Q $3 V 2 A$ & $98.02635^{\circ}$ & $W$ & $55.56227^{\circ}$ & $\mathrm{N}$ & 561407.9 & 6157793.5 & 14 \\
\hline NSA-ASP & R8V8A & $97.89260^{\circ}$ & $W$ & $55.67779^{\circ}$ & $\mathrm{N}$ & 569638.4 & 6170774.8 & 14 \\
\hline NSA-ASP & S9P $3 A$ & $98.87621^{\circ}$ & $W$ & $55.88576^{\circ}$ & $\mathrm{N}$ & 507743.3 & 6193371.6 & 14 \\
\hline NSA-ASP & $\mathrm{T} 4 \mathrm{U} 5 \mathrm{~A}$ & $98.04329^{\circ}$ & $W$ & $55.84757^{\circ}$ & $\mathrm{N}$ & 559901.6 & 6189528.2 & 14 \\
\hline$N S A-A S P$ & T 8 S 4A & $98.37041^{\circ}$ & $W$ & $55.91856^{\circ}$ & $\mathrm{N}$ & 539348.3 & 6197194.6 & 14 \\
\hline$N S A-A S P$ & $\mathrm{~V} 5 \times 7 \mathrm{~A}$ & $97.48565^{\circ}$ & $W$ & $55.97396^{\circ}$ & $\mathrm{N}$ & 594506.1 & 6204216.6 & 14 \\
\hline NSA-ASP & W0Y5A & $97.33550^{\circ}$ & $W$ & $56.00339^{\circ}$ & $\mathrm{N}$ & 603796.6 & 6207706.6 & 14 \\
\hline NSA-MIX & Q1V2M & $98.03769^{\circ}$ & $W$ & $55.54568^{\circ}$ & $\mathrm{N}$ & 560718.3 & 6155937.3 & 14 \\
\hline NSA-MIX & T0P 5M & $98.85662^{\circ}$ & $W$ & $55.88911^{\circ}$ & $\mathrm{N}$ & 508967.7 & 6193747.3 & 14 \\
\hline
\end{tabular}

\subsubsection{Spatial Coverage Map} None given.

\subsubsection{Spatial Resolution}

The spatial resolution is somewhat variable based on the altitude of the helicopter and the height of the trees and ground cover.

\subsubsection{Projection} None given.

\subsubsection{Grid Description Not applicable.}




\subsection{Temporal Characteristics}

\subsubsection{Temporal Coverage}

Observations were made during all three BOREAS 1994 IFCs, which occurred during the following periods:

IFC-1 24-May to 16-Jun

IFC-2 19-Jul to 10-Aug

IFC-3 30-Aug to 19-Sep

\subsubsection{Temporal Coverage Map}

Observations were made at several sites on the following dates:

$\begin{array}{rc}\text { Date } & \text { Study Area } \\ \text { 31-May-94 } & \text { SSA } \\ 1-J u n-94 & \text { SSA } \\ 4-J u n-94 & \text { SSA } \\ 6-J u n-94 & \text { SSA } \\ 7-J u n-94 & \text { SSA } \\ 8-J u n-94 & \text { NSA } \\ 10-J u n-94 & \text { NSA } \\ 21-J u l-94 & \text { NSA } \\ 22-J u l-94 & \text { SSA } \\ 23-J u l-94 & \text { SSA } \\ 24-J u l-94 & \text { SSA } \\ 25-J u l-94 & \text { SSA } \\ 28-J u l-94 & \text { SSA } \\ 4-A u g-94 & \text { NSA } \\ 8-A u g-94 & \text { NSA } \\ 6-S e p-94 & \text { NSA } \\ 8-S e p-94 & \text { NSA } \\ 9-\text { Sep-94 } & \text { NSA } \\ 13-\text { Sep-94 } & \text { NSA } \\ 15-S e p-94 & \text { SSA } \\ 16-S e p-94 & \text { SSA } \\ & \end{array}$

In addition to the still images from each IFC, videotapes exist for the dates indicated below:

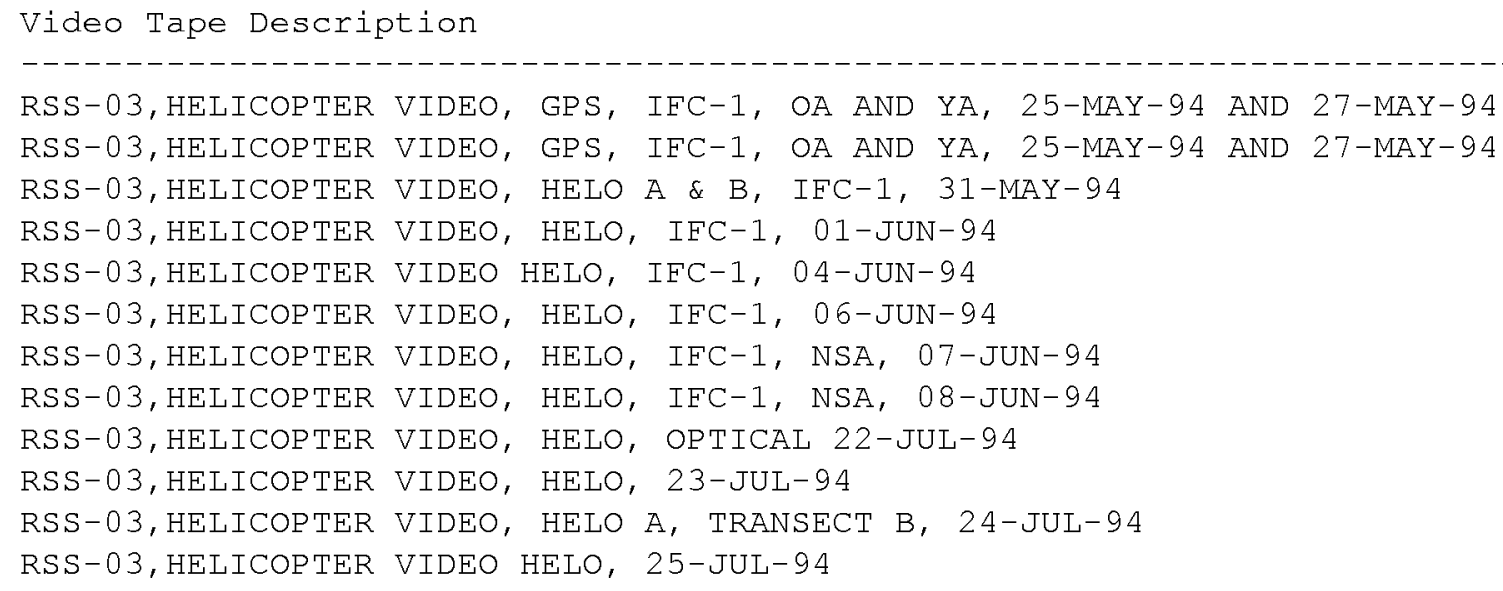


RSS-03, HELICOPTER VIDEO HELO, B HELO, 25-JUL-94

RSS-03, HELICOPTER VIDEO, HELO, A \& B 04-AUG-94

RSS-03, HELICOPTER VIDEO, C HELO, 04-AUG-94

RSS-03, HELICOPTER VIDEO, HELO A 08-AUG-94

\subsubsection{Temporal Resolution}

Measurements were collected as conditions permitted during each IFC. Each site was visited as often as possible during each IFC, with priority given to tower flux sites and category 1 auxiliary sites. Helicopter flight time was limited to approximately 2 hours by fuel constraints. As many sites as possible were visited during each flight.

\subsection{Data Characteristics}

\subsubsection{Parameter/Variable}

Video tapes and still frame imagery. The parameters contained in the video tape inventory file on the CD-ROM are:

Column Name
MEDIA_ID
MEDIA_DESCR

\subsubsection{Variable Description/Definition}

The still frames were digitized from the video tape as representative views of the sites. The video tapes are Beta and VHS format containing the collected video imagery. The descriptions of the parameters contained in the video tape inventory file on the CD-ROM are:

$\begin{array}{ll}\text { Column Name } & \text { Description } \\ \text { MEDIA_ID } & \text { The BORIS identifier assigned to the data/ } \\ & \text { information containing media. The form of the } \\ \text { MEDIA_DESCR } & \text { MEDIA_ID varies with each data set. } \\ & \text { The description of the information holding media. } \\ & \text { An example would be: RSS-03 Helicopter video } \\ & \text { tapes. IFC-1 OA and YA 25-MAY-1994 and } \\ & \text { 27-MAY-1994 (VHS and BETA formats) }\end{array}$

\subsubsection{Unit of Measurement}

There are no measurement units associated with the video tape or still frame imagery. The measurement units for the parameters contained in the video tape inventory file on the CD-ROM are:

$\begin{array}{ll}\text { Column Name } & \text { Units } \\ - & \\ \text { MEDIA_ID } & \text { [none] } \\ \text { MEDIA_DESCR } & \text { [none] }\end{array}$

\subsubsection{Data Source}

The images were gathered with a color, VHS video recorder. The source of the parameter values contained in the video tape inventory file on the CD-ROM are:

$\begin{array}{ll}\text { Column Name } & \text { Data } \\ & \\ \text { MEDIA_ID } & \text { [Assigned by BORIS] } \\ \text { MEDIA_DESCR } & \text { [Provided by RSS-03] }\end{array}$




\subsubsection{Data Range}

The following table gives information about the parameter values found in the video tape inventory file on the CD-ROM.

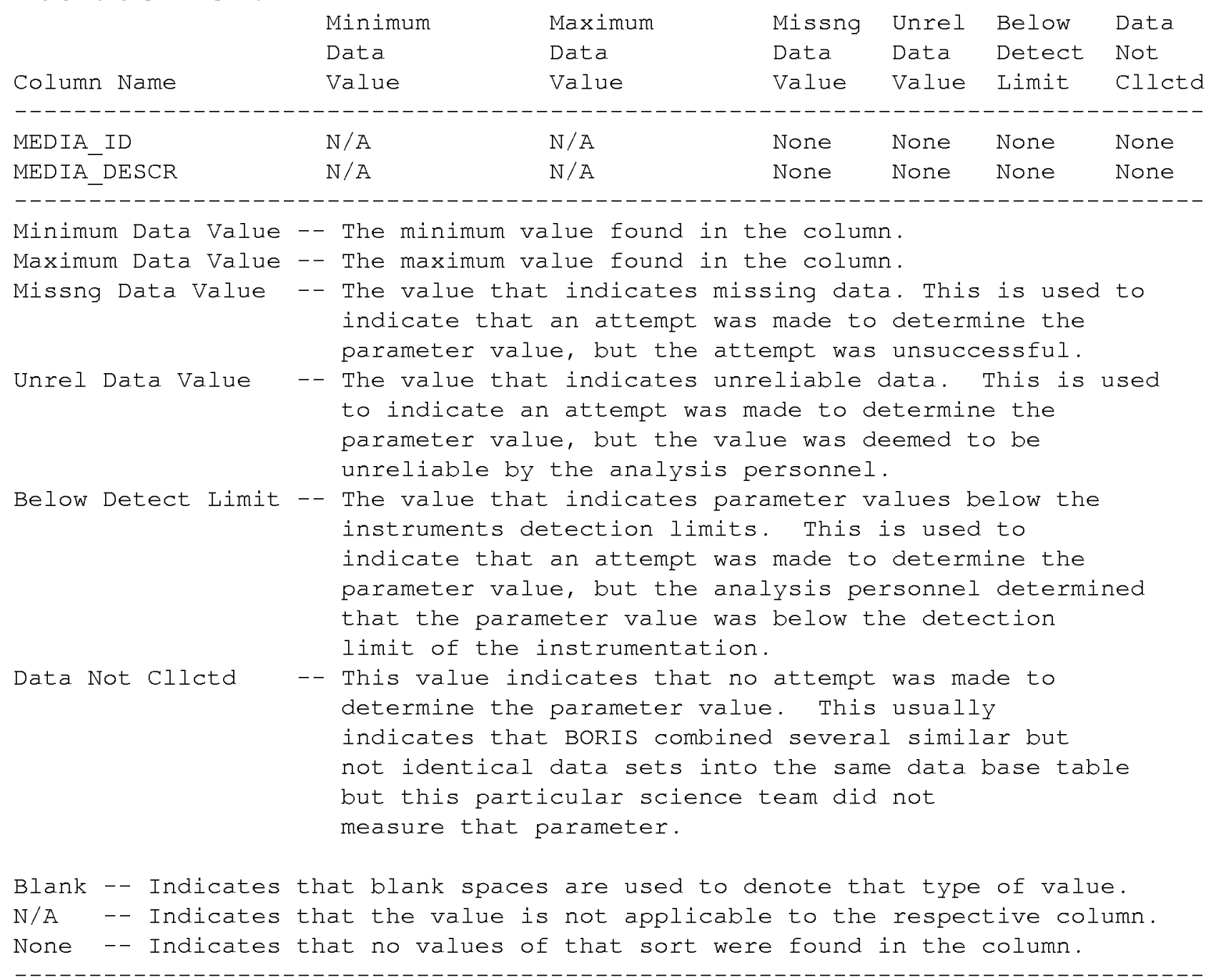

\subsection{Sample Data Record}

The following are wrapped versions of data records from the video tape inventory file on the CD-ROM.

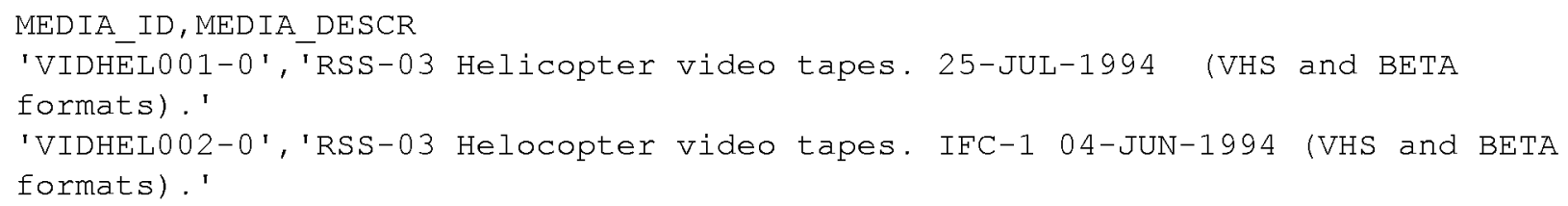




\section{Data Organization}

\subsection{Data Granularity}

The smallest unit of information for the video tapes is one video tape. The smallest unit of data for the still images is a single image.

\subsection{Data Format(s)}

The video tapes are stored in Beta and/or VHS format. The still images are stored in JPEG image files that are named with the date when and site where the imagery was acquired.

The Compact Disk-Read-Only Memory (CD-ROM) file of video tape inventory information contains American Standard Code for Information Interchange (ASCII) numerical and character fields of varying length separated by commas. The character fields are enclosed with single apostrophe marks. There are no spaces between the fields.

Each data file on the CD-ROM has four header lines of Hyper-Text Markup Language (HTML) code at the top. When viewed with a Web browser, this code displays header information (data set title, location, date, acknowledgments, etc.) and a series of HTML links to associated data files and related data sets. Line 5 of each data file is a list of the column names, and line 6 and following lines contain the actual data.

\section{Data Manipulations}

\subsection{Formulae \\ None given.}

\subsubsection{Derivation Techniques and Algorithms}

None given.

\subsection{Data Processing Sequence}

None given.

\subsubsection{Processing Steps}

None given.

\subsubsection{Processing Changes}

None given.

\subsection{Calculations}

None given.

\subsubsection{Special Corrections/Adjustments}

None given.

\subsubsection{Calculated Variables}

None given.

\subsection{Graphs and Plots}

None given. 


\section{Errors}

\subsection{Sources of Error}

None given.

\subsection{Quality Assessment}

Visual quality assessment during data collection. See reference list and helicopter logs. BOREAS Information System (BORIS) staff viewed some of the JPEG imagery to verify data format. Some of the video tape was viewed in the process of copying from Beta to VHS format.

\subsubsection{Data Validation by Source}

None given.

10.2.2 Confidence Level/Accuracy Judgment None given.

\subsubsection{Measurement Error for Parameters} None given.

\subsubsection{Additional Quality Assessments}

None given.

\subsubsection{Data Verification by Data Center}

See Section 10.2.

\section{Notes}

\subsection{Limitations of the Data}

None given.

\subsection{Known Problems with the Data}

None given.

\subsection{Usage Guidance}

The video imagery was taken to capture visual conditions at the site during data collection that can be referred to as necessary when using any of the helicopter data sets.

\subsection{Other Relevant Information}

None given.

\section{Application of the Data Set}

See Section 11.3.

\section{Future Modifications and Plans}

None. 


\section{Software}

\subsection{Software Description}

Avid VideoShop 3.0.2

\subsection{Software Access}

The software described is publicly available.

\section{Data Access}

The RSS-03 imagery and snapshots are available from the Earth Observing System Data and Information System (EOSDIS) Oak Ridge National Laboratory (ORNL) Distributed Active Archive Center (DAAC).

\subsection{Contact Information}

For BOREAS data and documentation please contact:

ORNL DAAC User Services

Oak Ridge National Laboratory

P.O. Box 2008 MS-6407

Oak Ridge, TN 37831-6407

Phone: (423) 241-3952

Fax: (423) 574-4665

E-mail: ornldaac@ornl.gov or ornl@eos.nasa.gov

\subsection{Data Center Identification}

Earth Observing System Data and Information System (EOSDIS) Oak Ridge National Laboratory (ORNL) Distributed Active Archive Center (DAAC) for Biogeochemical Dynamics http://www-eosdis.ornl.gov/.

\subsection{Procedures for Obtaining Data}

Users may obtain data directly through the ORNL DAAC online search and order system [http://www-eosdis.ornl.gov/] and the anonymous FTP site [ftp://www-eosdis.ornl.gov/data/] or by contacting User Services by electronic mail, telephone, fax, letter, or personal visit using the contact information in Section 15.1.

\subsection{Data Center Status/Plans}

The ORNL DAAC is the primary source for BOREAS field measurement, image, GIS, and hardcopy data products. The BOREAS CD-ROM and data referenced or listed in inventories on the CD-ROM are available from the ORNL DAAC.

\section{Output Products and Availability}

\subsection{Tape Products}

None.

\subsection{Film Products}

The video tapes are in both VHS and Beta format. 


\subsection{Other Products}

The still imagery is provided as files in JPEG format. These data are available on the BOREAS CD-ROM series.

\section{References}

\subsection{Platform/Sensor/Instrument/Data Processing Documentation}

Walthall, C., D.L. Williams, B. Markham, J. Kalshoven, and R. Nelson. 1996. Development and present configuration of the NASA GSFC/WFF helicopter-based remote sensing system. International Geosciences and Remote Sensing Symposium (IGARSS) Spring 1996, Lincoln, Nebraska.

\subsection{Journal Articles and Study Reports}

Newcomer, J., D. Landis, S. Conrad, S. Curd, K. Huemmrich, D. Knapp, A. Morrell, J. Nickeson, A. Papagno, D. Rinker, R. Strub, T. Twine, F. Hall, and P. Sellers, eds. 2000. Collected Data of The Boreal Ecosystem-Atmosphere Study. NASA. CD-ROM.

Sellers, P. and F. Hall. 1994. Boreal Ecosystem-Atmosphere Study: Experiment Plan. Version 1994-3.0, NASA BOREAS Report (EXPLAN 94).

Sellers, P. and F. Hall. 1996. Boreal Ecosystem-Atmosphere Study: Experiment Plan. Version 1996-2.0, NASA BOREAS Report (EXPLAN 96).

Sellers, P., F. Hall, and K.F. Huemmrich. 1996. Boreal Ecosystem-Atmosphere Study: 1994 Operations. NASA BOREAS Report (OPS DOC 94).

Sellers, P., F. Hall, and K.F. Huemmrich. 1997. Boreal Ecosystem-Atmosphere Study: 1996 Operations. NASA BOREAS Report (OPS DOC 96).

Sellers, P., F. Hall, H. Margolis, B. Kelly, D. Baldocchi, G. den Hartog, J. Cihlar, M.G. Ryan, B. Goodison, P. Crill, K.J. Ranson, D. Lettenmaier, and D.E. Wickland. 1995. The boreal ecosystem-atmosphere study (BOREAS): an overview and early results from the 1994 field year. Bulletin of the American Meteorological Society. 76(9):1549-1577.

Sellers, P.J., F.G. Hall, R.D. Kelly, A. Black, D. Baldocchi, J. Berry, M. Ryan, K.J. Ranson, P.M. Crill, D.P. Lettenmaier, H. Margolis, J. Cihlar, J. Newcomer, D. Fitzjarrald, P.G. Jarvis, S.T. Gower, D. Halliwell, D. Williams, B. Goodison, D.E. Wickland, and F.E. Guertin. 1997. BOREAS in 1997: Experiment Overview, Scientific Results and Future Directions. Journal of Geophysical Research 102(D24): 28,731-28,770.

\subsection{Archive/DBMS Usage Documentation None.}

\section{Glossary of Terms}

None. 


\section{List of Acronyms}

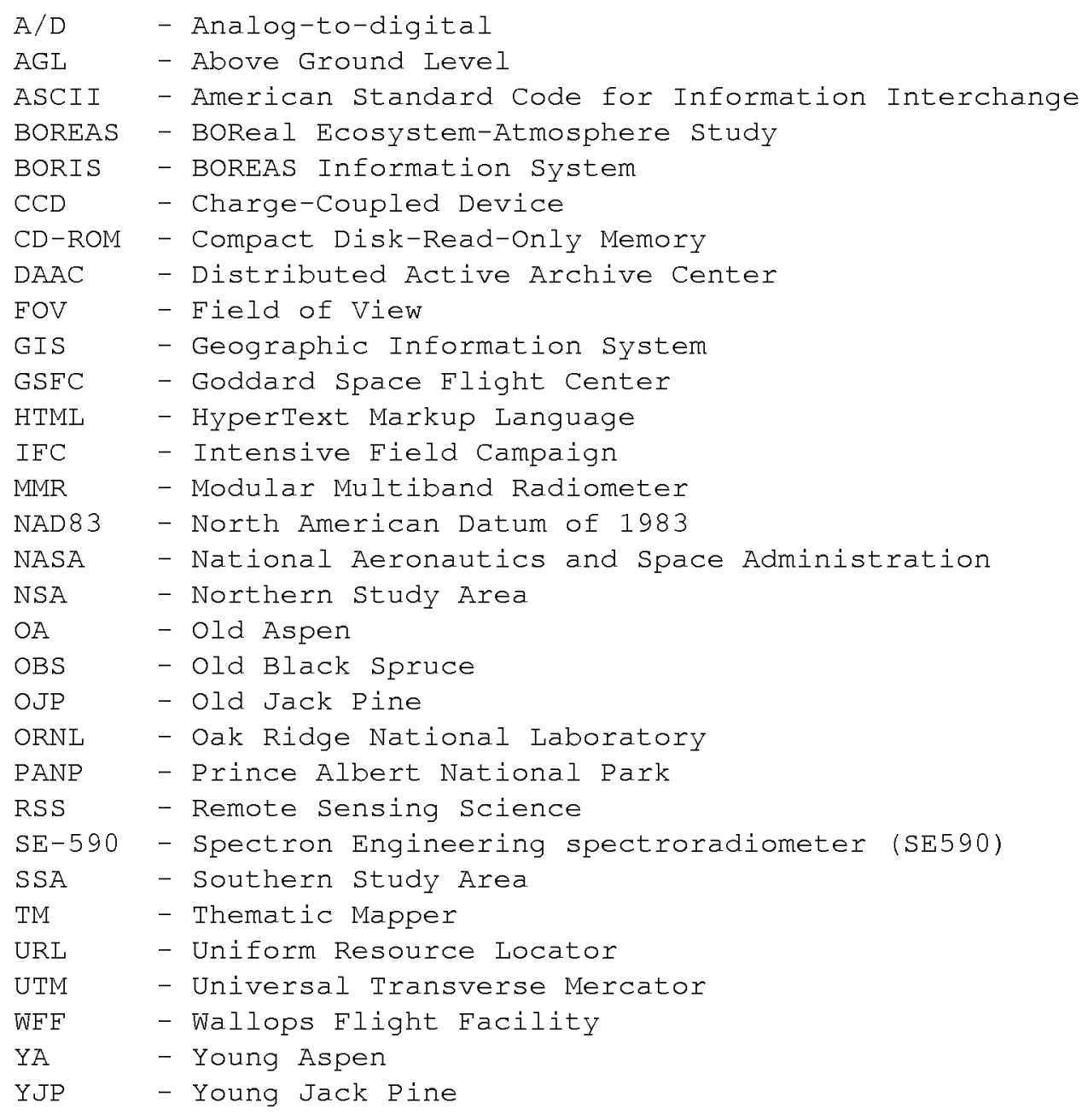

\section{Document Information}

\subsection{Document Revision Date}

Written: 30-Jun-1997

Last Updated: 31-Aug-1999

\subsection{Document Review Dates}

BORIS Review: 03-Dec-1998

Science Review:

\subsection{Document ID}

\subsection{Citation}

When using these data, please contact the individuals listed in Section 2.3 as well as citing relevant papers in Section 17.2. 
If using data from the BOREAS CD-ROM series, also reference the data as:

Walthall, C.L., "Biophysical Significance of Spectral Vegetation Indices in the Boreal Forest." In Collected Data of The Boreal Ecosystem-Atmosphere Study. Eds. J. Newcomer, D. Landis, S.

Conrad, S. Curd, K. Huemmrich, D. Knapp, A. Morrell, J. Nickeson, A. Papagno, D. Rinker, R. Strub, T. Twine, F. Hall, and P. Sellers. CD-ROM. NASA, 2000.

Also, cite the BOREAS CD-ROM set as:

Newcomer, J., D. Landis, S. Conrad, S. Curd, K. Huemmrich, D. Knapp, A. Morrell, J.

Nickeson, A. Papagno, D. Rinker, R. Strub, T. Twine, F. Hall, and P. Sellers, eds. Collected Data of The Boreal Ecosystem-Atmosphere Study. NASA. CD-ROM. NASA, 2000.

\subsection{Document Curator}

\subsection{Document URL}


Public reporting burden for this collection of information is estimated to average 1 hour per response, including the time for reviewing instructions, searching existing data sources, gathering and maintaining the data needed and completing and reviewing the collection of information. Send comments regarding this burden estimate or any other aspect of this collection of information including suggestions for reducing this burden, to Washington Headquaters Services, Directorate for Information Operations and Reports, 1215 Jefferson Davis Highway, Suite 1204, Arlington, VA 22202-4302, and to the Office of Management and Budget, Paperwork Reduction Project (0704-0188), Washington, DC 20503.
1. AGENCY USE ONLY (Leave blank)
2. REPORT DATE
July 2000
3. REPORT TYPE AND DATES COVERED
Technical Memorandum

4. TITLE AND SUBTITLE

Technical Report Series on the Boreal Ecosystem-Atmosphere Study (BOREAS)

BOREAS RSS-3 Imagery and Snapshots from a Helicopter-Mounted Video

Camera

\section{AUTHOR(S)}

Charles L. Walthall and Sara Loechel

Forrest G. Hall and Jaime Nickeson, Editors

7. PERFORMING ORGANIZATION NAME(S) AND ADDRESS (ES)

Goddard Space Flight Center

Greenbelt, Maryland 20771

5. FUNDING NUMBERS

923

RTOP: $923-462-33-01$

9. SPONSORING / MONITORING AGENCY NAME(S) AND ADDRESS (ES)

10. SPONSORING / MONITORING AGENCY REPORT NUMBER

National Aeronautics and Space Administration

Washington, DC 20546-0001

TM-2000-209891

Vol. 48

\section{SUPPLEMENTARY NOTES}

C.L. Walthall: U.S.D.A. Agricultural Research Service; S. Loechel: University of Maryland;

J. Nickeson: Raytheon ITSS

\begin{tabular}{l|l}
\hline 12a. DISTRIBUTION / AVAILABILITY STATEMENT & 12b. DISTRIBUTION CODE \\
Unclassified-Unlimited & \\
Subject Category: 43 & \\
Report available from the NASA Center for AeroSpace Information, \\
7121 Standard Drive, Hanover, MD 21076-1320. (301) $621-0390$.
\end{tabular}

13. ABSTRACT (Maximum 200 words)

The BOREAS RSS-3 team collected helicopter-based video coverage of forested sites acquired during BOREAS as well as single-frame "snapshots" processed to still images. Helicopter data used in this analysis were collected during all three 1994 IFCs (24-May to 16-Jun, 19-Jul to 10-Aug, and 30-Aug to 19-Sep), at numerous tower and auxiliary sites in both the NSA and the SSA. The VHS-camera observations correspond to other coincident helicopter measurements. The field of view of the camera is unknown. The video tapes are in both VHS and Beta format. The still images are stored in JPEG format.

\section{SUBJECT TERMS \\ BOREAS, remote sensing science, VHS camera.

\begin{tabular}{l|c} 
17. SECURITY CLASSIFICATION & 18. SECURITY CLASSIFICATION \\
OF REPORT & OF THIS PAGE \\
Unclassified & Unclassified
\end{tabular}

15. NUMBER OF PAGES

16

16. PRICE CODE
19. SECURITY CLASSIFICATION OF ABSTRACT

Unclassified
20. LIMITATION OF ABSTRACT

UL 
